\title{
Knowledge of Amyotrophic Lateral Sclerosis (ALS) in Pharmacy Students
}

\author{
Safila Naveed ${ }^{*}$, Asra Hameed and Syeda Maheen Nadeem \\ Faculty of Pharmacy, Jinnah University for Women, Karachi, Pakistan
}

*Corresponding author: Safila Naveed, Faculty of Pharmacy, Jinnah University for Women, Karachi, Pakistan, Tel: 923002621917; E-mail: safila117@yahoo.com

Rec date: Jul 16, 2013, Acc date: Sep 16, 2014, Pub date: Oct 25, 2014

Copyright: () 2015 Naveed S, et al. This is an open-access article distributed under the terms of the Creative Commons Attribution License, which permits unrestricted use, distribution, and reproduction in any medium, provided the original author and source are credited.

\begin{abstract}
A motor neuron disease, known as (ALS) Amyotrophic lateral sclerosis in which neuronal muscles becomes atrophic. There is a loss of control of the brain on voluntary muscles occurs. Signs and symptoms of the disease vary according to the condition of a patient. There is no specific diagnostic test and treatment yet for this disease. Our survey aimed to find out its awareness among the university students of Karachi, Pakistan. Data of 50 university students was collected and analyzed. A cross-sectional and random method was used to collect data. Different questions were asked the awareness regarding the disease among university students. Only $10 \%$ students have basic information regarding this disease. $2 \%$ students have information about the signs and symptoms, $2 \%$ students have information about the diagnosis, and $4 \%$ students have information regarding the treatment strategies of this motor neuron disease, Amyotrophic lateral sclerosis (ALS) in our survey. This survey proved that there is no awareness about ALS or only a negligible awareness among university students in the Karachi city. Even there were many students who heard this term "Amyotrophic lateral sclerosis (ALS)" first time in their lives.
\end{abstract}

Keywords: Motor neuron disease; Amyotrophic lateral sclerosis (Als); Neuronal muscles; Atrophic; Voluntary muscles

\section{Introduction}

A type motor neuron disorders is Amyotrophic lateral sclerosis (ALS) or Lou Gehrig's disease [1]. It is a syndrome of progressive deterioration involving the brainstem, cortices Pinal tract, and anterior horn cells of the spinal cord. ALS developing risk is high between the ages of 50 years and 75 years [2]. Rather than a single disease entity, ALS considered as a syndrome due to its indication of heterogeneity in phenotype, genetic predisposition, and pathological substrate in Clinical, pathological and genetic advances [3]. On the basis of site of onset, disease phenotype is classified. Limb symptoms are present in approximately $65 \%$ of patients, whereas $30 \%$ patients have symptoms of bulbar dysfunction in the form of dysphagia or dysarthria. There is also a respiratory-onset disease expensed by $5 \%$ of the ALS patients [3]. Initially weight loss symptoms has also been reported [4]. Up to $25 \%$ of patients with ALS have evidence of cognitive impairment, mainly executive dysfunction, and frontotemporal dementia is experienced by $15 \%$ patients [3]. The clinical and pathogenic overlap between ALS and some other neurodegenerative diseases tends to support the hypothesis that a shared environmental and genetic susceptibility underlies some neurodegenerative phenotypes [5].

\section{Diagnosis}

No definitive diagnostic test for ALS exists. The combination of suggestive clinical signs with negative laboratory tests and imaging studies for other pathologies supports the diagnosis. The diagnosis is established by excluding other causes of progressive upper motor neuron and lower motor neuron dysfunction [3].

\section{Treatments}

Riluzole is the only drug proven to modify the ALS, and to improve the survival. 11 Clinical care is based on symptom management. Further improvements in survival will depend on advances in understanding the origins and spread of this syndrome. Symptom control and preservation of quality of life remain the cornerstones of management for patients with ALS.

\section{Aim of Study}

There are several cases reported in Pakistan therefor we have to decide check the awareness of this disease and also by this we can give information to health care professionals regarding the disease.

The basic aim of this study is to check the awareness about this disease and by compiling all information regarding ALS in this paper is very useful for health care profession. We have done this type of surveys and by reading these research article students of pharm D and MBBS will be well aware of this disease [6-12].

\section{Methodology}

This is a survey based study on the awareness of Amyotrophic lateral sclerosis (ALS). A cross-sectional and random method was use to collected data from university students about the knowledge of Amyotrophic lateral sclerosis (ALS) in the month of May-June, 2014 in Karachi city. A specially designed questionnaire was used for data collection. Data of 50 students $(n=50)$ was collected and analyzed. Different questions were asked from the subjects to collect the data to conclude the awareness rate in university students about ALS. Questions were asked on the knowledge, sign and symptoms, diagnosis and treatment strategies of ALS. 
Citation: Naveed S, Hameed A, Nadeem SM (2014) Knowledge of Amyotrophic Lateral Sclerosis (ALS) in Pharmacy Students. Brain Disord

Page 2 of 4

\section{Data Analysis}

We have used tables and graphs for analysis of our data obtained. All the data were analyzed in SPSS version 19. The questions asked from students are given below.

What is Amyotrophic lateral sclerosis (ALS)?

How can we diagnose (ALS)?

What are the signs and symptoms?

What are the treatments for (ALS)?

\section{Result}

According to our survey on the awareness of Amyotrophic lateral sclerosis (ALS) the knowledge about ALS in university students of Karachi city is found very less. Only 5 out of 50 university students have knowledge about ALS, only a single student was there who know about the signs and symptoms and diagnosis of ALS out of 50 students. There were 2 students who know about the treatment strategies of ALS.

\section{Discussion}

In our survey on the awareness of a motor neuron disease, Amyotrophic lateral sclerosis (ALS) among the university students, different questions were asked from 50 students $(n=50)$. Four questions asked from subjects to check their knowledge level about the ALS.

\begin{tabular}{|l|l|l|l|l|}
\hline \multicolumn{2}{|l|}{ Frequency } & Percent & Valid Percent & $\begin{array}{l}\text { Cumulative } \\
\text { Percent }\end{array}$ \\
\hline no & 45 & 90.0 & 90.0 & 90.0 \\
\hline yes & 5 & 10.0 & 10.0 & 100.0 \\
\hline Total & 50 & 100.0 & 100.0 & \\
\hline
\end{tabular}

There were 2 equal probabilities to answer either yes or no. Tables 1-4 give results of ALS awareness regarding term, diagnosis treatment, etc. and Table 5 shows statistic of these groups. Figures 1-4 shows results of awareness.

\begin{tabular}{|l|l|l|l|l|l|}
\hline \multicolumn{2}{|c|}{} & Frequency & Percent & Valid Percent & $\begin{array}{l}\text { Cumulative } \\
\text { Percent }\end{array}$ \\
\hline \multirow{3}{*}{ Valid } & no & 49 & 98.0 & 98.0 & 98.0 \\
\cline { 2 - 6 } & yes & 1 & 2.0 & 2.0 & 100.0 \\
\cline { 2 - 6 } & Total & 50 & 100.0 & 100.0 & \\
\hline
\end{tabular}

Table 2: Knowledge about sign symptoms of ALS.

\begin{tabular}{|l|l|l|l|l|l|}
\hline \multicolumn{2}{|l|}{} & Frequency & Percent & Valid Percent & $\begin{array}{l}\text { Cumulative } \\
\text { Percent }\end{array}$ \\
\hline \multirow{3}{*}{ Valid } & no & 49 & 98.0 & 98.0 & 98.0 \\
\cline { 2 - 6 } & yes & 1 & 2.0 & 2.0 & 100.0 \\
\cline { 2 - 6 } & Total & 50 & 100.0 & 100.0 & \\
\hline
\end{tabular}

Table 3: Knowledge about diagnosis of ALS.

\begin{tabular}{|l|l|l|l|l|l|}
\hline \multicolumn{2}{|l|}{} & Frequency & Percent & Valid Percent & $\begin{array}{l}\text { Cumulative } \\
\text { Percent }\end{array}$ \\
\hline \multirow{3}{*}{ Valid } & no & 48 & 96.0 & 96.0 & 96.0 \\
\cline { 2 - 6 } & yes & 2 & 4.0 & 4.0 & 100.0 \\
\cline { 2 - 6 } & Total & 50 & 100.0 & 100.0 & \\
\hline
\end{tabular}

Table 4: Knowledge about Treatment of ALS.

Table 1: Knowledge about ALS.

\begin{tabular}{|l|l|l|l|l|l|}
\hline \multicolumn{2}{|l|}{} & Knowledge & Sign symptoms & Diagnosis & Treatment \\
\hline $\mathrm{N}$ & Valid & 50 & 50 & 50 & 50 \\
\cline { 2 - 6 } & Missing & 0 & 0 & 0 & 0 \\
\hline \multirow{2}{*}{ Mean } & .1000 & .0200 & .0200 & .0400 \\
\hline Std. Error of mean & .04286 & .02000 & .02000 & .02799 \\
\hline Median & .0000 & .0000 & .0000 & .0000 \\
\hline Mode & .00 & .00 & .00 & .00 \\
\hline Std. Deviation & .30305 & .14142 & .14142 & .19795 \\
\hline
\end{tabular}

Table 5: Statistics of participant. 


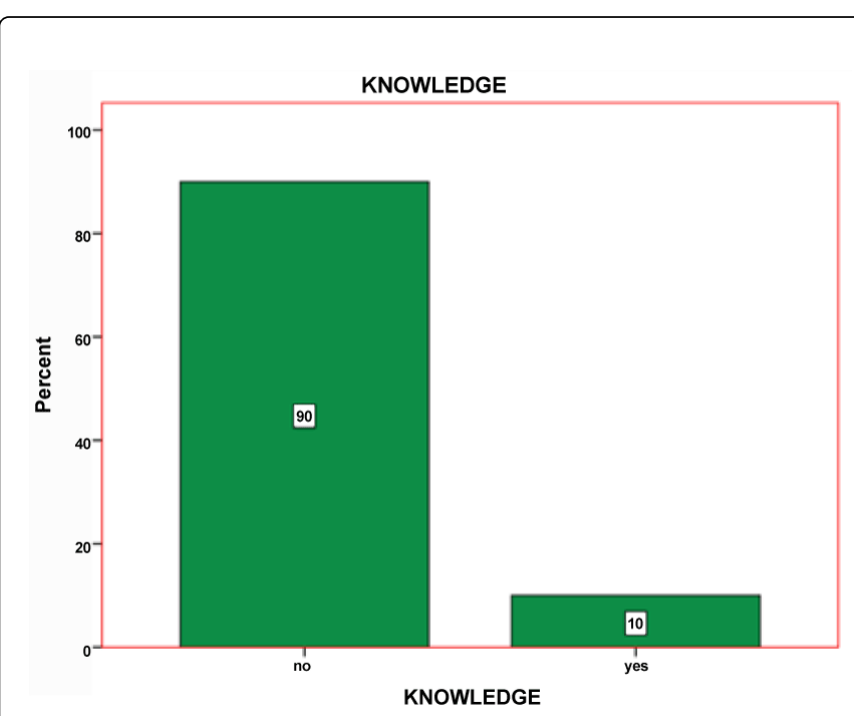

Figure 1: Knowledge about ALS.

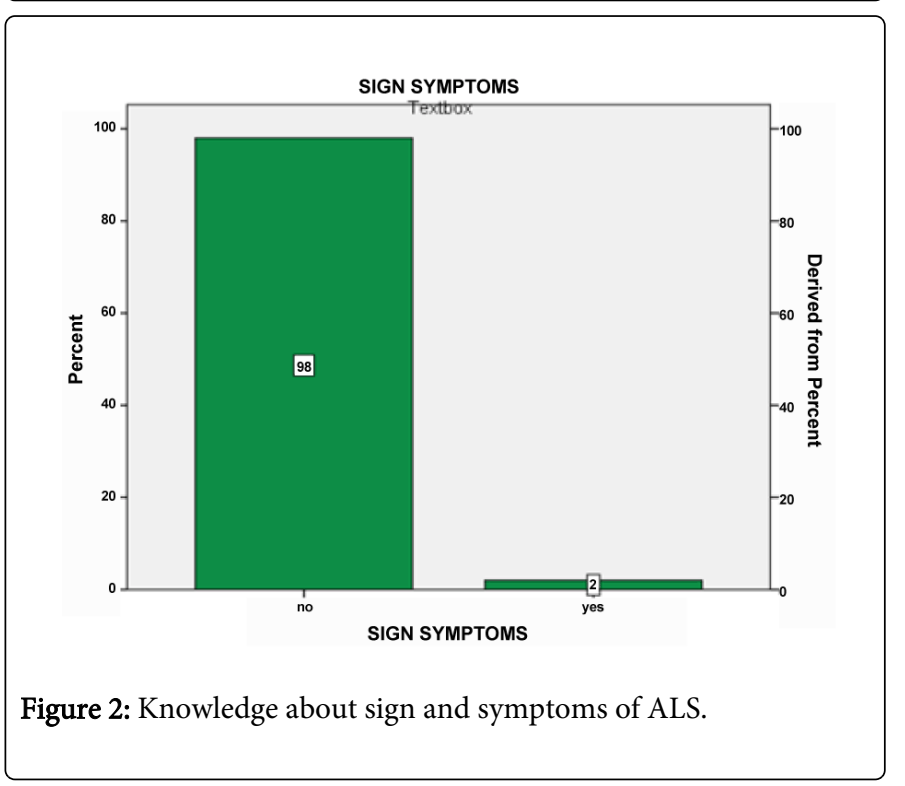

In our survey the first question was asked about the basic knowledge regarding the disease Amyotrophic lateral sclerosis. This question was asked from 50 university students. 45 out of 50 university students have no basic information about this motor neuronal degenerative disease. Even some students heard this term first time in their lives. There were only 5 university students in our survey of 50 students who have information regarding ALS.

The next question in our survey was asked about the signs and symptoms regarding the disease Amyotrophic lateral sclerosis. This question was asked from 50 university students. 49 out of 50 university students have no information about the signs and symptoms of this motor neuronal degenerative disease. There was only a single university student in our survey of 50 students who have information regarding the signs and symptoms of ALS.

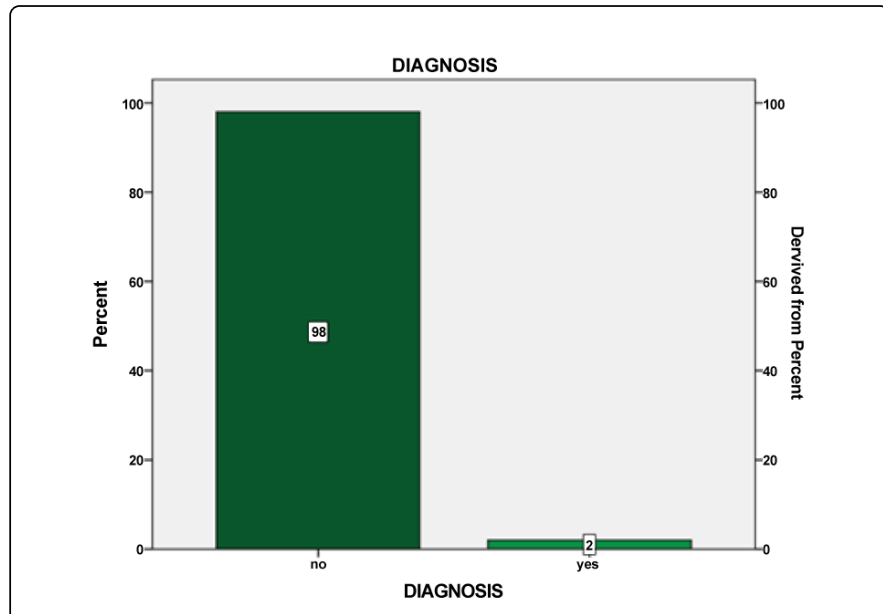

Figure 3: Knowledge about diagnosis of ALS.

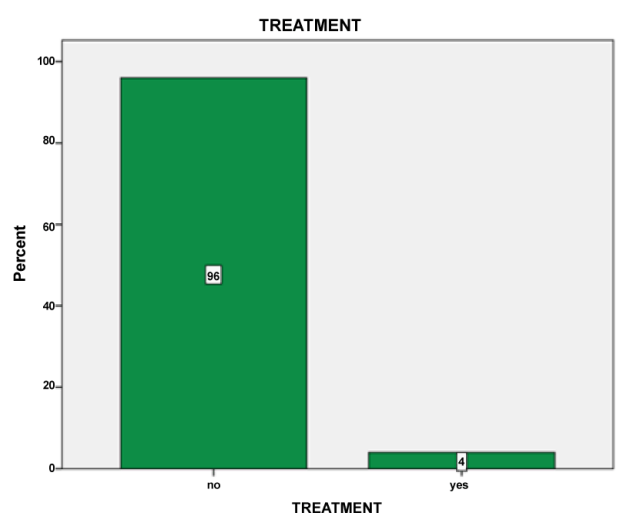

Figure 4: Knowledge about treatment of ALS.

The next question in our survey was asked about the diagnosis of disease Amyotrophic lateral sclerosis. This question was asked from 50 university students. There is no way yet to diagnose the ALS directly so 49 out of 50 university students have no information about the diagnosis of this motor neuronal degenerative disease. There was only a single university student in our survey of 50 students who have information regarding the series of diagnostic tests of ALS.

The last question in our survey was asked about the treatment strategies of disease Amyotrophic lateral sclerosis. This question was asked from 50 university students. There is no cure of ALS, treatment may help to relive the symptoms and keep the patient calm and comfortable. 48 students out of 50 university students have no information about the treatment strategies of this motor neuronal degenerative disease. There were only a pair of university student in our survey of 50 students who have information regarding the treatment strategies of ALS. These types of awareness studies helpful for medical student about disease, symptoms, treatment and precaution etc [6-12]. 
Citation: Naveed S, Hameed A, Nadeem SM (2014) Knowledge of Amyotrophic Lateral Sclerosis (ALS) in Pharmacy Students. Brain Disord

\section{Conclusion}

After our survey regarding the awareness of ALS, we find there is only negligible awareness in the university students about this disease. Therefore we concluded that the knowledge of ALS in student is not enough to dial uncertain mishap of the ALS \& they must aware to the ALS to treat others more better.

\section{Acknowledgement}

We would like to thank the management of university for support.

\section{References}

1. Charcot JM (1874) De la sclacrose latacrale amyotrophique [French] Progras Madical 2: 325

2. Hardiman O, van den Berg LH, Kiernan MC (2011) Clinical diagnosis and management of amyotrophic lateral sclerosis. Nat Rev Neurol 7: 639-649.

3. Logroscino G, Traynor BJ, Hardiman O, Chiò A, Mitchell D, et al. (2010) Incidence of amyotrophic lateral sclerosis in Europe. J Neurol Neurosurg Psychiatry 81: 385-390.

4. Ferguson TA, Elman LB (2007) Clinical presentation and diagnosis of amyotrophic lateral sclerosis. NeuroRehabilitation 22: 409-416.
5. Przedborski S, Vila M, Jackson-Lewis V (2003) Neurodegeneration: what is it and where are we? J Clin Invest 111: 3-10.

6. Naveed S, Waheed N, Ghayas S (2014) Awareness regarding blastocystosis disease; a Neglected Zoonotic disease MJPMS Mintage journal of Medical and pharmaceutical Sciences 3: 15-16.

7. Naveed S, Ghayas S, Was HKi, Azam M, Siddiqui M, et al. (2014) Awareness of Hepatitus B in Pharm D students: Survey based study (DHR-IJPS) 5: 98-104.

8. Naveed S (2014) Knowledge and Attitude about Crimean Congo Hemorrhagic Fever (CCHF) Amongst Local Residents Of Karachi, Pakistan, Accepted J App Pharm 6: 166-170.

9. Naveed S, Syed R, Zafar A, Tariq T, Wasif N, et al. (2014) Prevalence Of Oral Submucous Fibrosis And Use of Tobacco And Related Products Mintage journal of Medical and pharmaceutical Sciences 3: 4-6

10. Naveed S, Qamar F, Zainab S, Sarwer G (2014) A Survey Study on awareness of Hepatitis $\mathrm{C}$ in different groups. World journal of pharmaceutical Sciences 2: 449-454.

11. Naveed S, Hashmi F, Khan A, Salahuddin N (2014) Awareness about Thalassemia : A survey Report MJPMS Mintage journal of Medical and pharmaceutical Sciences 3: 18-19.

12. Naveed S, Siddiqui A, Rais A, Usman S, Zaidi IJ, et al. (2014) General Awarness Of Human Papilloma Virus Vaccine Against Cervical Cancer. MJPMS Mintage journal of Medical and pharmaceutical Sciences 3: $11-14$. 